\title{
Pharmacognostic, antiplasmodial and antipyretic evaluation of the aqueous extract of Vernonia amygdalina leaf
}

\author{
Paul Chukwuemeka ADIUKWU ${ }^{1 *}$, Agaba AMON $^{1}$ and Grace NAMBATYA ${ }^{2}$ \\ ${ }^{I}$ Department of Pharmacology and Therapeutics, Faculty of Medicine, Mbarara University of Science and \\ Technology, P.O. Box 1410 Mbarara, Uganda. \\ ${ }^{2}$ Natural Chemotherapeutic Research Laboratories, P.O. Box 4864 Kampala, Uganda. \\ ${ }^{*}$ Corresponding author, E-mail: paulemy@ must.ac.ug, +256703861052
}

\begin{abstract}
The impeding safety challenges to the use of herbs have made qualitative and quantitative evaluation of herbal preparations a necessity. This study was aimed at evaluating the pharmacognostic and pharmacological properties of $V$. amygdalina leaf. Methods used include standard procedure for macroscopic and microscopic examinations; ash and extractive values determination; and quantitative evaluation of phytochemicals of the leaf aqueous extract. 4-day antiplasmodial suppression test using mice and antipyretic evaluation in rats induced pyrexia by i.p administration of $15 \% \mathrm{w} / \mathrm{v}$ Saccharomyces cerevisiae were carried out. Data showed presence of calcium oxalates and animocytic stomata. Extractive values suggest high aqueous soluble constituents. Saponin at $9.18 \% \mathrm{w} / \mathrm{w} \pm 0.19$, among the phytochemicals evaluated was highest. Ash values: total ash $11.33 \% \mathrm{w} / \mathrm{w} \pm 0.15$ and acid insoluble ash $1.89 \% \mathrm{w} / \mathrm{w} \pm 0.19$, were obtained. Parasite suppression on day 4 and dose induced body temperature decrease, were significant $(P \leq 0.05)$ for all the 3 dose levels of the extract used. Study agrees with folkloric use of the leaf extract in malaria fever but suggests substantial antipyretic property of the leaf.
\end{abstract}

(C) 2011 International Formulae Group. All rights reserved.

Key Words: Ash and extractive values, parasite suppression, temperature decrease.

\section{INTRODUCTION}

Herbal medicine has been estimated by World Health Organization (WHO) to be used by $80 \%$ of the world population. In India, the herbal drug market is worth one billion dollars while the export of plant based crude drugs is around 80 million dollars (Palav and D'mello, 2006). In Uganda, accessibility to health facilities has increased, especially in the rural areas (UBOS, 2005). However, the Uganda Ministry of Health estimated that out of $90 \%$ of pregnant women who make contact with health facilities only $38 \%$ of them actually delivered there. $30 \%$ of these women make use of traditional birth attendants (TBAs) experts in herbal medications within their communities (Kironde et al., 2003). Such drive for the use of plants as medicines has made regular ethno-pharmacological study a necessity (Damintoti et al., 2007).

Herbal medicines are prepared from materials of plant origin which are prone to contamination, deterioration and composition variation. Because of these, quality control of herbal formulations offers a host of problems which makes standardization an important challenge. A prelude to solving these 
problems, include the selection of therapeutically effective plant materials.

Vernonia amygdalina leaf (commonly known as bitter leaf) is one of the most widely used herbal preparation, especially in Sub-Saharan Africa. Despite the various pharmacological studies on the use of herbal medicines (Iwalokun et al., 2004, 2006; Ojiako and Nwanjo, 2006; Anoka et al., 2008; Taiwo et al., 2009; Asuquo et al., 2010), there are still information draught respect to the identity of therapeutically effective and safe quality of the herb (World Health Organization, 2005). To address some of the impeding challenges in using the herb for malarial therapy therefore, this study was aimed at evaluating the pharmacognostic properties of the leaf, and the antiplasmodial and antipyretic properties of the leaf aqueous extract.

\section{MATERIALS AND METHODS}

Reagents, drugs and test agents

Acetylsalicylic acid (ASA) (Pinewood, Caprin $\left.^{\circledR}\right)$ Vernonia amvgdalina leaf, chloroquine phosphate (Astra Zeneca ${ }^{\circledR}$ ) and sterile pre-packed normal saline (Albert David, India) and KY jelly ${ }^{\circledR}$ (as lubricant) were used. Bismuth nitrate, tartaric acid, potassium iodide, strong potassium dichromate, sodium chloride, sodium hydroxide, acetic acid, ammonia water, glycerol, chloral hydrate, sulphuric acid and hydrochloric acid were all purchased from BDH sales representative (Kampala, Uganda). All the solvents (ethanol, diethyl ether, $n$ butanol, chloroform) were of analytical grade.

\section{Plant material and extraction}

The fresh leaves of Vernonia amygdalina were collected between June and July, 2007 (raining season) in the south western part of Uganda. The leaf was identified by Julius Lejju (botanist) of the Biology Department, Faculty of Science, Mbarara University of Science and Technology. The specimen was retained with voucher number 16-20 in the department. The plant leaves were shade air-dried and ground into a coarse powder. Using a similar method as employed by ethnics, the dried coarse powder was sieved to a $2000 \mathrm{~g}$ fine powder and macerated for $3 \mathrm{hrs}$ in warm $\left(<80{ }^{\circ} \mathrm{C}\right)$ distilled water at a ratio of $131 \mathrm{~g}$ to 9 litres with intermittent shaking, using a laboratory rotator. The obtained extract was filtered while warm using filter paper. The filtrate was further filtered using a buckner filter assemblage (aided by a suction pump) and subsequently dried using an oven (at $\leq 80{ }^{\circ} \mathrm{C}$ ) to obtain $360 \mathrm{~g}$ (18\% yield) of residue. The obtained residue was stored in a desiccator for further use.

\section{Phytochemical screening of aqueous extract}

Preliminary screening of the aqueous extract for phytochemicals was carried out using standard procedures (Harborne, 1973; Trease and Evans, 1983).

\section{Pharmacognostic evaluation}

The macroscopy of the matured (fresh) leaf was carried out using a magnifying lens which gave a detail macro-morphology of the leaf. The transverse section of the leaf was cut, cleared using chloral hydrate, mounted on the electronic microscope (Nikkon Y52-H) with dilute glycerol and examined for microscopic characteristics (Heinrich, 2004). Similarly, the microscopy of the dried powder of the leaf was examined after clearing with choral hydrate solution.

Standard procedure as documented in the official literature was adopted in determining the alcohol, aqueous and chloroform extractive values using the dried leaf powder (World Health Organization, 2003). The total ash value and acid insoluble ash value (using $0.1 \mathrm{M}$ hydrochloric acid), were determined according to Kokate (2000). Quantitative assessment for crude alkaloid, tannin and saponin in the aqueous extract were carried out according to standard procedures (Obadoni and Ochuko, 2001; Beckett and Stenlake, 2004; Kokate et al., 2004). Using dragendorff's test for alkaloid, ferric chloride test for tannin and foaming test for saponin, the identities of the phytochemicals were confirmed. 


\section{Pharmacological evaluation Animals}

Wistar rats (120-200 g) and albino mice (20-25 g) fed with standard live stock feed at the Animal Facility of Mbarara University of Science and Technology were selected for this study. The animals were kept in cages at room temperature and moisture, under a naturally illuminated environment with a 12:12 hour dark/light cycle. Animals had access to tap water ad libitum.

The National Institute of Health (NIH) guide for the care and use of laboratory animals (NIH, 1978), approved by the Institutional Ethical Committee, was adopted for the animal protocol.

Plasmodial (blood schizontocidal) 4 day suppression study of the aqueous extract

Using similar procedure as described by Abosi and Raseroka (2003), 25 albino mice were inoculated intraveinously (i.v) with standard inoculums. The standard inoculums were prepared by diluting chloroqine sensitive Plasmodium berghei infected blood samples, taken from the tail of prior infected albino mouse, with phosphate buffered saline such that $0.2 \mathrm{ml}$ of the solution contained $1 \times 10^{7}$ infected erythrocytes. To ensure a harmonised result in parasitaemia, all the mice for the experiment were inoculated using inoculums prepared with the blood of the same infected mouse, on day 0 . The mice were randomly divided into five groups of five mice each and administered orally (p.o), normal saline (placebo) $20 \mathrm{ml} / \mathrm{kg}$ to group 1 , chloroquine phosphate (standard) $5 \mathrm{mg} / \mathrm{kg}$ to group 2 while groups 3-5 received $125 \mathrm{mg} / \mathrm{kg}$, $250 \mathrm{mg} / \mathrm{kg}$ and $500 \mathrm{mg} / \mathrm{kg}$ of the extract.

Blood sample was collected from the tail of each mouse on day 0 (before inoculating) and day 1 to day 4 , immediately before the next dose or $24 \mathrm{hrs}$ after the previous dose administration. At each instance, thin blood films were made, stained with Giemsa (for 45 minutes) and microscopically (Nikkon Y52-H, Japan) examined. Level of daily parasitaemia was taken as the number of red blood cells (rbc) infected with the parasite (counted in 5 different fields). Relative malaria parasite suppression (RMPS) was calculated in percentage as $([\mathrm{B}-\mathrm{C}] / \mathrm{B}) \quad \mathrm{x} 100 \quad$ (B parasitaemia due to placebo in group 1 ; $\mathrm{C}$ parasitaemia due to either standard in group 2 or extract in groups 3-5)

\section{Antipyretic activity study of the aqueous extract}

The procedure as described by Okokon and Onah (2004) was adopted for this study. Using an anal thermometer probe, wistar rats with $<37{ }^{\circ} \mathrm{C}$ basal body temperatures were selected for the study. After the induction of pyrexia, animals were randomly divided into five groups of five rats each and allowed to starve over night in their respective cage. Pyrexia was induced by intra peritoneal (i.p) administration of $15 \% \mathrm{w} / \mathrm{v}$ brewer's yeast (active dry Saccharomyces cerevisiae) in normal saline solution at a dose of $10 \mathrm{ml} / \mathrm{kg}$ body weight. $20 \mathrm{hrs}$ after yeast administration, the body temperature of each animal was taken before oral (p.o) administration of normal saline (placebo) $5 \mathrm{ml} / \mathrm{kg}$ to group 1 , ASA (standard) $250 \mathrm{mg} / \mathrm{kg}$ to group 2 and the extract $(400 \mathrm{mg} / \mathrm{kg}, 600 \mathrm{mg} / \mathrm{kg}$ and 800 $\mathrm{mg} / \mathrm{kg}$ ) to groups 3-5 respectively. All the doses were administered using a canula/syringe assemblage. 4 hours after dose administration, the body temperature reading of each animal was taken.

\section{Statistical analysis of data}

All the results were expressed as means \pm SEM (standard error of mean). In the antiplasmodial and antipyrexia study, ANOVA was used to analyse values within groups and student T-test, to analyse data between groups. $P$ value $\leq 0.05$ was taken as level of significance in all cases.

\section{RESULTS}

\section{Phytochemical screening}

Phytochemical screening was positive for alkaloids, saponins, tannins, sophisticated lactones, triterpenoids, reducing sugars, amino acids, flavonoids, terpenoids, and cardiotonic 
glycosides presence. However, quinine test was negative.

\section{Pharmacognostics evaluation}

Macro-morphological examination of the leaf revealed a green coloured simple leaf with symmetric base, reticular venation, puberscent surface, acute apex, serrated margin and a lanceolate (oval) shape. The histological characteristic of the leaf as provided by the microscopic examination showed the presence of anomocytic stomata, multicellular (6.3-8.2-12.7 $\mu \mathrm{m})$ covering nonglandular trichomes, calcium oxalate crystals (Rosette 2.3-2.4-3.5 $\mu \mathrm{m}$ and prism 1.2-1.6-2.5 $\mu \mathrm{m})$ and phloem fibres (6.8-7.4-8.4 $\mu \mathrm{m})$. Alcohol extractive value $12.65 \% \mathrm{w} / \mathrm{w} \pm 0.34$, aqueous extractive value $24.80 \% \mathrm{w} / \mathrm{w} \pm 0.87$ and chloroform extractive value $4.7 \% \mathrm{w} / \mathrm{w} \pm$ 0.50 were obtained. Mean values of $11.33 \%$ $\mathrm{w} / \mathrm{w} \pm 0.15$ total ash and $1.89 \% \mathrm{w} / \mathrm{w} \pm 0.19$ acid insoluble ash were also obtained. Quantitative assessment produced $2.48 \% \mathrm{w} / \mathrm{w} \pm 0.14$ of alkaloidal, $7.28 \% \mathrm{w} / \mathrm{w} \pm 0.15$ of tannin and
$9.18 \% \mathrm{w} / \mathrm{w} \pm 0.19$ of saponin contents in the aqueous extract of the dried leaf powder.

\section{Antiplasmodial activity}

The aqueous extract 4-day plasmodial suppression study showed a dose dependent response which was significant $(P \leq 0.05)$ for the three dose levels of the extract used (Table 1). However, data for RMPS activity was lower with the extract in groups 3-5 than with the standard (chloroquine phosphate) in group 2.

\section{Antipyretic activity}

ANOVA indicates no significant $(P \leq$ $0.05 \alpha)$ difference in the induced body temperature in the animals within and among groups. Student T-test analysis showed a significant $(P \leq 0.05)$ difference in dose induced body temperature decrease for the extracts and standard (table 2). This decrease was higher in the extract which also, produced a dose dependent response.

Table 1: Aqueous extract induced plasmodial suppression on day 4 in Mice.

\begin{tabular}{|c|c|c|c|c|c|}
\hline Group & 1 & 2 & 3 & 4 & 5 \\
\hline \multirow{2}{*}{ Doses } & \multirow{2}{*}{$\begin{array}{c}\text { normal } \\
\text { saline } 20 \\
\text { ml/kg }\end{array}$} & \multirow{2}{*}{$\begin{array}{c}\text { CQ } \\
\text { Phosphate } 5 \\
\text { mg/kg }\end{array}$} & \multicolumn{3}{|c|}{ Aqueous Extract } \\
\hline & & & $125 \mathrm{mg} / \mathrm{kg}$ & $250 \mathrm{mg} / \mathrm{kg}$ & $500 \mathrm{mg} / \mathrm{kg}$ \\
\hline Weight (g) & $20.53 \pm 0.53$ & $20.48 \pm 0.49$ & $20.14 \pm 0.13$ & $20.31 \pm 0.41$ & $20.44 \pm 0.45$ \\
\hline $\begin{array}{l}\text { Day } 4 \text { Parasite } \\
\text { Count }\end{array}$ & $16.40 \pm 1.14$ & $* 2.60 \pm 0.55$ & $\begin{array}{c}* 10.40 \pm \\
1.14\end{array}$ & $* 7.40 \pm 1.14$ & $* 6.60 \pm 0.89$ \\
\hline $\begin{array}{l}\text { Relative Mean } \\
\text { Parasite } \\
\text { Suppression } \\
(\%)\end{array}$ & 0 & 84.15 & 36.59 & 54.88 & 59.76 \\
\hline
\end{tabular}


Table 2: Aqueous extract induced body temperature decrease in rats.

\begin{tabular}{|c|c|c|c|c|}
\hline \multirow[b]{2}{*}{ Group } & \multirow[b]{2}{*}{ Dose } & \multirow{2}{*}{$\begin{array}{c}\text { Mean basal } \\
\text { body temp. }\left({ }^{0} \mathrm{C}\right)\end{array}$} & \multicolumn{2}{|c|}{ Mean body temp. $\left({ }^{0} \mathrm{C}\right)$} \\
\hline & & & $\begin{array}{l}20 \text { hrs after yeast } \\
\text { administration }\end{array}$ & $\begin{array}{l}24 \mathrm{hrs} \text { after yeast or } 4 \mathrm{hrs} \\
\text { after dose administration }\end{array}$ \\
\hline 1. Placebo & Normal saline $5 \mathrm{ml} / \mathrm{kg}$ & $38.39 \pm 0.10$ & $39.02 \pm 0.11$ & 39.010 .11 \\
\hline 2. Standard & Acetylsalicylic acid $250 \mathrm{mg} / \mathrm{kg}$ & $38.50 \pm 0.09$ & $39.12 \pm 0.10$ & $* 38.97 \pm 0.07$ \\
\hline 3. Test & Aqueous extract $400 \mathrm{mg} / \mathrm{kg}$ & $38.59 \pm 0.16$ & $39.21 \pm 0.18$ & $* 38.66 \pm 0.17$ \\
\hline 4. Test & Aqueous extract $600 \mathrm{mg} / \mathrm{kg}$ & $38.46 \pm 0.19$ & $39.09 \pm 0.20$ & $* 38.18 \pm 0.15$ \\
\hline 5. Test & Aqueous extract $800 \mathrm{mg} / \mathrm{kg}$ & $38.54 \pm 0.19$ & $39.08 \pm 0.13$ & $* 37.58 \pm 0.19$ \\
\hline
\end{tabular}




\section{DISCUSSION}

As the drive for the use of medicinal herbs especially, in the rural communities increase, there is the need for studies that will assist in safe and effective use of herbal formulations. In this study, the pharmacognostic property of the leaf of $V$. amydalina was evaluated. Using such property as identity of the herb, subsequent antiplasmodial and antipyretic evaluations of the leaf aqueous extract were evaluated. Data obtained in the macroscopic and microscopic examinations complied with previous description of the leaf (Akinpelu, 1999; Ibrahim et al., 2004). Identification of insoluble calcium oxalate crystals supports literature documentation on the limited presence of soluble calcium salts in Asteraceae (Hall, 1979).

Due to the nature of herbal formulations, the acceptability of $V$. amydalina prepation can be further supported by obtained quantitative data like the extractive and ash values which are usually expressed as maximum limits (Gokhale and Kokate, 2004). The acid insoluble ash value $(1.89 \% \mathrm{w} / \mathrm{w} \pm 0.19)$, which complies with literature limits, can be an added standardization tool (Handa and Kapoor, 2004).

An earlier study quantified constituents relevant to the nutritive value of $V$. amygdalina (Argheore et al., 1998) but, very little information has been provided regarding potential secondary metabolites of medicinal value. The need to provide qualitative and semi-quantitative data on crude drug constituents has been highlighted by the World Health Organisation (Sapna et al., 2005). Usually expressed in minimum percentage, the data obtained for phytochemials (alkaloid, tannin and saponin) in this study, can serve as important quality control tool for the herbal formulation.

The four day plasmodial suppression test, though significant $(P \leq 0.05)$ for the extract doses used, gave data lower than those from previous antiplasmodial activity studies
(Tona et al., 1999; Abosi and Raseroka, 2003). Adopting oral administration as in this evaluation, could present limits to absorption, contrary to the parenteral route of administration used by earlier studies. The increasing dose with increasing response, implying increasing blood concentration, supports this concept which may explain the lower antiplasmodial activity obtained. The mechanism of the aqueous extract was not explained by this test, however, agents possessing antiplasmodial property are considered to possess inhibitory activity against calcium mobilisation caused by plasmodial invasion of host cell (Nwodo et al., 2010).

Brewer's yeast can be used to induce pyrexia similar to the effect of lipopolyssacharides, in laboratory animals. Such induction activates the arachidonic acid pathway and has been associated with elevated prostaglandin $\mathrm{E}_{2}\left(\mathrm{PGE}_{2}\right)$ level in the hypothalamus (Walter et al., 2003). Antipyretic agents have been shown to antagonise this $\mathrm{PGE}_{2}$ elevation by inhibiting the activity of cyclo-oxygenase to suppress pyrexia (David et al., 2001). The aqueous extract in the antipyretic test showed significant $(P \leq 0.05)$ and dose dependent antipyretic activity, suggesting a possible mechanism of action which could be similar to most antipyretic agents like ASA. A similar antipyretic study of the root extract of $V$. amygdalina showed lesser activity than that obtained with the leave extract in this study (Okokon and Onah, 2004).

\section{Conclusion}

The result of the plasmodial suppression test in mice agrees with the folkloric use of the herb for malarial therapy among the ethnics. The antipyretic property as seen in the test with rats suggests with some certainty, a reason for the use of the herb in common ailments which produces pyrexia. These evaluated pharmacological activities were based on the identified pharmacognostic characteristics. These characters of the leaf 
especially, the quantitative characteristics can be contributory tools in standardisation and quality control of $V$. amydalina leaf formulations. Further quantitative study on the phytochemical constituents is worth undertaking to support the quality control of the herbal preparation.

\section{ACKNOWLEDGEMENTS}

The authors are grateful to the Vice Chancellor of Mbarara University of Science and Technology (MUST), Uganda, Prof. F.I.B Kayanja for his invaluable advice and input, $\mathrm{Mr}$ Adiukwu P.J for his technical contribution, the Faculty of Medicine Ethical Committee (MUST) for the review of the study proposal and also, the staff and management of Natural Chemotherapeutic Research Laboratories, Kampala for availing their facilities for this study.

\section{REFERENCES}

Abosi AO, Raseroka BH. 2003. In vivo antimalarial activity of Vernonia amygdalina. Br. J. Biomedical Sci., 60: 89-91.

Akinpelu DA. 1999. Antimicrobial activity of Vernonia amygdalina leaves. Fitoterapia, 70(4): 432.

Anoka AN, Adzu B, Amon A, Byarugaba D, Diaz-Llera S, Bangsberg D. 2008. The analgesic and antiplasmodial activities and toxicology of Vernonia amygdalina. J. Med. Food, 11(3): 574-580.

Argheore EM, Makkar HPS, Becker K. 1998. Feed value of some browse plants from the central zone of Delta State. Nig. Trop. Sci., 38(2): 97-104.

Asuquo OR, Igiri AO, Akpan JE, Akpaso MI. 2010. Cardioprotective potential of Vernonia Amygdalina and Ocimum gratissimum against Streptozotocin (Stz) - induced diabetes in Wistar rats. The Internet J. Trop. Med., 7(1).

Beckett AH, Stenlake JB. 2004. Solvent extraction method: Determination of alkaloids in crude drugs and galenicals. In Practical Pharmaceutical Chemistry $\left(4^{\text {th }}\right.$ edn, 1st Indian edn). CBS: New Delhi, India; 228-247.

Damintoti K, Wendyame MCN, Lassina O, Dénise PI, Antonella C, Nikiéma JB, Simpore J, Colizzi V, Traore AS. 2007. African ethnopharmacology and new drug discovery. Intl. J. Biomed. Pharma. Science, 1(1): 61-69.

David M, Aronoff MD, Eric G, Neilson MD. 2001. Antipyretics: mechanisms of action and clinical use in fever suppression. AJM., 111(4): 304-315.

Gokhale SB, Kokate CK. 2004. Introduction to parts of a plant. In Practical Pharmacognosy ( $7^{\text {th }}$ edn, Vol. 4). Nirali Prakashan: Pune; 3.

Guide for the Care and Use of Laboratory Animals (revised). 1978. NIH Publication No. 83-23. National Institute of Health, Bethesda, MD.

Hall MA. 1976. Plant Structure, Function and Adaptation. The Macmillan Press ltd: Hong Kong; 4-8.

Handa S, Kapoor K. 2004. Drug evaluation and standardization. In Text Book of Pharmacognosy (2 ${ }^{\text {nd }}$ edn, Vol. 6). Vallabh Prakashan: Delhi; 73-74.

Harborne JB. 1973. Phytochemical Methods. Chapman and Hall: London; 113.

Heinrich M. 2004. Production, standardization and quality control. In Fundamentals of Pharmacognosy and Phytotherapy. Churchill Livingston: London; 144-143.

Ibrahim G, Abdurahman M, Katayal A. 2004. Pharmacognostic studies on the leaves of Vernonia amygdalina Del. (Asteraceae). Nig. J. Nat. Prod. \& Med., 8: 8-10.

Iwalokun BA, Bamiro SB, Durojaiye OO. 2004. An antimicrobial evaluation of Vernonia amygdalina (Compositae) against gram-positive and gram-negative bacteria from Lagos, Nigeria. W. Afr. J. Pharmacol. Drug Res., 19.

Iwalokun BA, Efedede BU, Alabi-Sofunde JA, Oduala T, Magbagbeola OA, Akinwande AI. 2006. Hepatoprotective and antioxidant activities of Vernonia amygdalina on acetaminophen-induced 
hepatic damage in mice. J. Med. Food, 9(4): 524-530.

Kironde S, Lukwago J, Ssenyong R. Scaling the frontier - should traditional birth attendants also be used to provide nevirapine for PMTCT in Uganda? Afr Health Sci., 3(2): 102-103

Kokate CK. 2000. Practical Pharmacognocy $4^{\text {th }}$ edition. Nirali Prakashan: Pune; 149.

Kokate CK, Purohit P, Gokhale B. 2004. Analytical pharmacognosy. In Pharmacognosy $\quad\left(26^{\text {th }}\right.$ edn). Nirali Prakashan: Pune; 108-255.

Nwodo OFC, Omeje EO, Obiezue RN, Ozoemena NF. 2010. Inhibition of plasma calcium availability may contribute to anti-malarial activity. Nig. J. Biochem. Mol. Biol., 25(1): 39-43.

Obadoni BO, Ochuko PO. 2001. Phytochemical studies and comparative efficacy of the crude extracts of some homeostatic plants in Edo and Delta States of Nigeria. Global J. Pure Appl. Sci., 8: 203-208.

Ojiako O, Nwanjo H. 2006. Is Vernonia amygdalina hepatotoxic or hepatoprotective? Response from biochemical and toxicity studies in rats. Afr. J. Biotechnol., 5(18): 1648-1651.

Okokon JE, Onah MI. 2004. Pharmacological studies on root extract of Vernonia amygdalina. Nig. J. Prod. \& Med., 8: 5961.

Palav YK, D'mello PM. 2006. Standardization of selected Indian medicinal herbal raw materials containing polyphenols as major phytoconstituents. Indian $J$. Pharm. Sci., 68: 506-9.

Sapna S, Uma M, Suganthi A, Ravi TK. 2005. WHO Guidelines for Herbal Drug Standardization. Available online: www.Pharmainfo.net. [Access Date: 2005].

Taiwo IA, Odeigah PGC, Ogunkanmi LA. 2009. The glycaemic effects of Vernonia amygdalina and $V$. tenoreana with tolbutamide in rats and the implications for the treatment of diabetes mellitus. $J$. Sci. Res. Dev., 11: 122-130.

Tona L, Cimanga RK, Mesia K. 1999. Antimalarial activity of 20 crude extracts from nine african medicinal plants used in Kinshasa, Congo. J. Ethnopharmacol., 68: 193-203.

Trease G, Evans M. 1983. Textbook of Pharmacognosy (12th edn). Bailliere Tindall: London; 343-383.

Uganda Bureau of Statistics (UBOS). 2005. Statistical Abstract. Kampala, Uganda Bureau of Statistics: 256.

Walter F. 2003. Medical Physiology: A Cellular and molecular approach. Elsevier/Saunders, 58: 1300.

World Health Organization. 2003. International Pharmacopoeia (3rd edn, Vol. 5). WHO Press: Geneva.

World Health Organization. 2005. National Policy on Traditional Medicines and Regulation of Herbal Medicines. Report of a WHO global survey: Geneva. 